\title{
Smart City and Resources Optimisation in Urban Communities
}

\author{
Dumitru Zamfir \\ Adrem, Bucharest, Romania
}

\begin{abstract}
The following represents the efforts, among other things, to introduce some considerations for decision-makers of state administration institutions which are empowered to increase efficiency of financial resources usage in order to contribute to optimization of citizens relation, leading to significant increase of relation with the citizens targeting improvement of individual and collective comfort, as well as increase of their relation with common area, including communication between local administration for the benefit of citizens and community. The study was realized by means of EU smart cities project and concept research in order to understand the way the mechanisms works versus EU objectives. It is a conventional approach, based on observation, strongly focused on theoretical research. Best practice examples may be identified through research and they may validate recommendations for future interventions, which may influence the evolution of smart cities, as well as their enrollment to European strategy objectives, emphasizing the population needs in great urban areas. Each city was examined using online information sources (local administration websites, such as a smart city website) mentioned in relevant literature. Throughout this process, concerns for smart city implementation were evaluated. The analysis itself is based on alignment of project portfolio objectives and characteristics for each city, as well as alignment of European strategy relevant objectives, while research is focused on innovative strategy series that can be practically developed in a performant smart city, identifying transversal themes and smart city solutions which may potentially be copied in different cities in Romania based on other European cities experience.
\end{abstract}

Keywords: smart city, best practices, strategy

\section{Introduction}

There are many definitions of smart cities. Some of them focus on information and communication technologies (ICTs) both as infrastructure and technological incentive, while extensive definitions include social economical, administrative, and complex approaches, such as usage of social participation used to increase sustainability, quality of life, and urban welfare.

Through this research, a smart city is regarded as busy geographical area where public problems are addressed by means of ICT-based solutions, and several interested parties' partnership (Capgemini Consultin, 2013). These solutions are developed and perfected by means of integrated initiatives of discreet projects aligned as activity and/or multi-layered infrastructure network.

The strategies and initiatives of a smart city must include at least one of the following characteristics (objectives and/or ways of functioning): smart management, smart people (smart communities), smart life, smart mobility, smart economy, and smart environment. These characteristics represent the purposes interested parties participate to smart city initiatives (e.g., to solve environmental problems).

Dumitru Zamfir, Engineer, associate professor, Ph.D., COO of Adrem Group of Companies, Bucharest, Romania. 
The means to achieve these objectives include several components: material, financial, organizational and informational resources and technologies, procedures, norms, or standards. These components could be already present or may be custom-made to be used in smart city initiatives.

Therefore, the components provide base elements of smart city initiatives and include three types: technological, human, and institutional.

\section{Perspectives}

World urban population is expected to double by 2050. Until 2030, six out of 10 persons will live in a city and until 2050 seven of 10 persons will live in a city. In real terms, the number of urban area inhabitants will increase with almost 60 million people every year. The more urban the planet become, the smarter the cities need to become.

Major urbanization requires new and innovative methods to manage urban life complexity; it needs new approaches of overpopulation related matters, energy consumption, resources management, and environmental preservation.

In this respect, smart cities seem not only an innovative modus operandi for future urban life, but also as key strategy for fighting poverty and inequality, unemployment, and energy management, including healthcare, education, and population protection.

The core of smart city idea originates in creating and connecting human capital, social capital, and ICT technology in order to generate a larger and more sustainable economic development and improved life quality (City Protocol Society, 2015). Smart cities have been defined mainly in six dimensions or axes:

- smart economy;

- smart mobility;

- smart environment;

- smart people (smart communities in education, culture, and healthcare);

- smart life;

- smart management.

Policies coordination along these dimensions reflects positive feedback between cities development and urbanization; cities draw people, while population and infrastructure availability enables economical and society development (NYC Tech Talent Pipeline, 2015). But this feedback itself does not answer expectations to gain benefits as problems related to uncontrolled mega-cities growth widely demonstrates it. The connections between economical, social, and environmental growth are not scalable while cities expand, and so is the balance evolution of functional support and existence support in these communities (Connected Smart Cities Network, 2015). So, their beneficial evolution must be facilitated by a combination of framework conditions of communications and executive information infrastructure. In this way, a platform is provided for administrations, companies, and citizens to communicate and work together and also benefit from city's progress.

Among global profile of urban development, smart city is an important base for further extension of the city. Worldwide, at the level of emerging economies, the European competitor desires the implementation of large smart city programmes. USA shall invest around 41 billion USD over the next 20 years in improving services and products infrastructure using Internet of Things (IoT) technology, in order to achieve a smart integrated concept of life quality management for city inhabitants. India intends to spend 66 billion EUR to 
develop seven smart cities along industrial corridor Delhi-Mumbai 10 using a mix of public-private partnership (80\%) and investments in harbour infrastructure financed from public funds (20\%). Also, China follows a smart cities strategy as part of its efforts to stimulate economical development and poverty eradication. As poverty in China is mainly a rural phenomenon, the programme aims to attract the workers from rural areas to smart cities later seen as urban centres of workforce involvement.

Smart city concept may be regarded as acknowledging the increased importance, even critical, of ICT for improvement of city competitiveness, as well as for ensuring a more sustainable future, in enterprise networks, technologies, infrastructure, consumption, energy, spaces, and interhuman connections (see Appendix A).

In a smart city, these networks connected to each other, reciprocally supporting, and feeding one another. The technology and data collection used in smart city should be capable to (Arup \& University College London, 2014):

- constantly collect, analyse, and distribute data about the city in order to optimize efficiency and effectiveness in the pursuit of competiveness and durability;

- communicate and share this kind of data and information around the city using common definitions and standards which ensures easy access;

- activate multi-functionally, offering solutions to multiple problems from a holistic perspective of the city.

Finally, an important additional feature, yet often disconsidered, of smart city concept is the city ICT support network. This network is outside city management control, but allows essential communications within the area, country, and part of global and European urban networks.

As a whole, ICT infrastructure allows a smart city to:

- collect data, information about communities and smart organizations;

- redesign relations between administration and private sector, non-profit organisations, communities, and citizens;

- ensure the existence of synergies and interoperability for all domains and policy systems in the whole community (e.g., transportation, energy, education, healthcare, utilities, etc.);

- stimulate innovation, for instance, by means of open data, laboratories, and technology hubs.

Although ICT infrastructure is an important component, smart city cannot simply be created by means of sensors implementation, networks, and analysis. Smart city estimations and characteristics correlations are important when improving efficiency (Crutzen, Bounazef \& Qian, 2018). In the worst case scenario, this may lead to a vertical approach of processes for economic development (see Appendix B).

\section{Smart Cities and European Strategy}

Objectives of "smart city" initiatives are, generally, aligned with those of the strategies for innovating and developing of the city, as well as with European strategy global objectives. This is not surprising; aspects are widely recognized, and settling the objectives at the city level, but also regional and European level, requires constant efforts for open-mindness and widely participation.

The characteristics of smart city initiatives reflect the level of understanding of the current situation of urban agglomeration and real needs they have. There are at least three different reasons for the follow-up of smart city strategies (Arup \& Department for Business, Innovation and Skills, 2013):

- Including smart city characteristics acknowledged as benchmarks (e.g., environment and innovative usage of ICT) may be motivated by the desire to attract enterprises in the city or to participate to EU-funded smart 
city projects.

- It is appropriate to include characteristics related to the areas where the city or the country is extremely poor if the critical mass, scale economies, applicability, and smart city political halo effect may be used to approach collective problems that resisted the solution through "regular" channels.

- Including the characteristics which are related to areas with a certain local power (e.g., environment characteristics between smart cities of Northern member states) provides a profitable platform for building smart city coalition. "Cost of failure" is low and the risk of failure is reduced, starting from solid and efficient technologies. Such initiatives stimulates knowledge exchange with other fields of interest-a city with strengths in an area may develop them as "smart city" for experience sharing with other cities whose strength covers the issues the former faces.

The competition between various objective levels (Europe 2020 Strategy, smart city strategies, and smart city specific initiatives) is only approximative, pointing out that Europe 2020 Strategy serves to stimulate and harmonize local action, and also that other factors provides uniqueness to each smart city (EuroEuropean Parliament, 2014). They include the gravity of various local problems; the strategic force behind inclusion of different characteristics above mentioned; variations in city and project limits; strengths, weaknesses, and specific motivations of parties locally interested; and cultural norms that favour or inhibit efficient partnership between interested parties from government, enterprises, to civil society.

Apparently, there is a clear difference between cities: some follow a mix of characteristics through numerous initiatives on the whole; others want to use a differentiated portfolio of specialized initiatives which support only few multi-objectives initiatives to reinforce a reduced number of specialized initiatives mainly focused on the most important characteristics (Copenhagen Capacity, 2014; Crutzen, Bounazef \& Qian, 2018).

This suggests that smart city initiatives are regarded both as instruments to approach specific problems and as a way to build a community of interest or a general awareness of the potential of such commune initiatives, and to provide a platform for the continuous progress that adapts the changing circumstances (Copenhagen Solutions Lab., 2015).

Most of the initiatives are targeted to contribute to a smart, sustainable, and inclusion favourable growth. Environmental problems and green solutions seem to be their main concern; almost $50 \%$ of the sampled initiatives address environmental problems by means of energy efficiency of the buildings or smarter transportation alternatives as part of whole during multi-annual programme to implement smart city (Ding, Zhang \& Zhao, 2017).

\section{European Strategy}

European strategy represents EU strategy to encourage economic growth and employment in the region in order to create an intelligent economy, durable, and inclusion favourable. In order to achieve these targets, main objectives out of five domains were nominated at national and European level, including employment, research and development, climate change and energy, education, and poverty and social exclusion. Table 1 presents objectives at European level.

"Smart city" initiatives may be considered useful instrument for cities to achieve their objectives. Cities are urban agglomeration serving as cultural, economic, and administrative center. Smaller towns with significant number of inhabitants may be around them, representing highly populated areas. As a result, cities as smart entities may be extremely appropriate for initiatives that targets local public properties problems, such as energy 
and climate change. In addition, the effects may be very visible, especially in comparison with low population density areas. The inhabitants' density and diversity (both population and business environment) enable reciprocal acknowledgement of problems, critical mass mobilization, and effective re-distribution and roles and responsibility monitorization. These are several possible uses and characteristics of smart city initiatives:

- European strategy energetic objective may be approached through initiatives which are focused on smart environment or smart mobility.

- The initiatives regarding smart economy and smart people are focused on education and employment objectives, which include digital competences development into becoming more accessible, and can also support European strategy objectives on workforce.

- The initiatives regarding smart administration and smart living address poverty and social exclusion through measures that include improvements of life standards, with focus on citizens connectivity (including electronic governance) when using open data to identify accessible workplaces and collective and individual participative requirements.

- Most of smart city initiatives have the potential to increase innovative economic growth and research and development. They are financed from various sources, including government and private companies, which share a common interest in this field inside multi-annual programme. In order to contribute to achieve the innovation, research, and development objective by means of additional incentive of private sector incentive in the field of research and development, it is essential that projects are evaluated and that lessons learnt serve for further development.

Table 1

Objectives of European Strategy

\begin{tabular}{ll}
\hline Focus area & Targets \\
\hline Employment & 75\% of 20-64 year olds to be employed \\
\hline R\&D and innovation & 3\% of the EU's GDP (public and private combined) to be invested in R\&D or innovation \\
\hline \multirow{2}{*}{ Climate change and energy } & Greenhouse gas emissions to be $20 \%$ (or even 30\%, if the conditions are right) lower than 1990 \\
\hline Education & 20\% of energy from renewables \\
\hline & Reduce school drop-out rates below 10\% \\
\hline Poverty and social exclusion & At least 40\% of 30-34 year olds have completed third level education \\
\hline
\end{tabular}

Note. Source: European Commission (2013).

In reality, a smart city initiative also targets improvement of the concept versus the series of objectives of European strategy. For instance, a project which improves mobility may facilitate transfer of persons to the most appropriate school or workplace (contributing to employment and education objectives). This, in return, may contribute to attenuate the problems caused by poverty and social exclusion localization, even if the impact is probably lower than the primary contribution to achieving the energy and environment objectives.

\section{Smart City Solutions and Best Practices}

The success factors for smart city go and solution implementation are bound to a clear vision of citizens, administration, and local enterprises involvement, as well as efficient process of conceptual and executive integration of actions to implement smart city solutions which are ICT-based and generates significant effects 
in improvement of life conditions.

Not all solutions identified in the context of a smart city programme contribute to achieving European strategy objectives, and not all solutions that contribute to its objectives are ICT-based. Most solutions are not implemented yet and are still during planning or pilot stage (EuroEuropean Parliament, 2014).

It is important to take into account local context when economically evaluating smart city solutions. Cost-benefit analysis at solution level must be analysed, and feasibility of analysed solutions should be possible in the medium and long term with positive net result.

\section{Conclusions}

Cities are complex systems which are characterized by a massive number of interconnected subsystems: enterprises, different types of transportation means, water and energy networks, and different services and utilities. Population growth and urbanization imply a series of technical, social, economical, and organizational issues that tend to endanger economical and ecological viability of cities. Rapid urban population growth has generated traffic jams, pollution, and vulnerabilities. Furthermore, the focus is on-the-way latest solutions on life and urban forecasting approaches may ensure further viability and prosperity in urban areas, as well as may remove vulnerabilities generated by calamities.

Technological systems may be managed through optimizations and may become efficient only when integrated accordingly. Digitalization, as well as other technologies, allows creation of integrated networks that provide social, environmental, and economic benefits for all, as an opportunity to improve quality of life. As a result, smart cities agendas will be included in the urban development projects; although they require huge investments, they provide fresh business opportunities for different interested parties in multi-annual programmes for improvement of citizens' life quality in urban agglomeration which become every day more and more numerous.

\section{References}

Arup \& Department for Business, Innovation and Skills. (2013). The Smart City Market: Opportunities for the UK. BIS Research Paper No. 136. Retrieved from https://www.gov.uk/government/uploads/system/uploads/attachment_data/file/249423/ bis-13-1217-smart-city-market-opportunties-uk.pdf

Arup \& University College London. (2014). Delivering the Smart City: Governing Cities in the Digital Age. Retrieved from https://www.arup.com/-/media/arup/files/publications/d/delivering_the_smart_city_full_report.pdf

Capgemini Consulting. (2013). The Digital Talent Gap: Developing Skills for Today’s Digital Organizations. Retrieved from https://www.capgemini.com/resource-file-access/resource/pdf/the_digital_tal-ent_gap27-09_0.pdf

City Protocol Society. (2015). City Anatomy: A Framework to Support City Governance, Evaluation and Transformation. Retrieved from http://www.cptf.cityprotocol.org/CPAI/CPA-I_001_Anatomy.pdf

Connected Smart Cities Network. (2015). Open \& Agile Smart Cities. Retrieved from http://connectedsmartcities.eu/open-agile-smart-cities/

Copenhagen Capacity. (2014). Smart City-Enstyrkepositioni Region Hovedstad. Retrieved fromhttp://www.copcap.com/newslist/danish/spi-samarbejdet-lofter-smart-city-udfordringer-og-poten-tialer-i-region-hovedst aden

Copenhagen Solutions Lab. (2015). New project “Select for Cities". Retrieved from http://cphsolutionslab.dk/new-project-select-for-cities/

Crutzen, N., Bounazef, D., \& Qian, W. (2018). Developing Sustainability Mobility Controls: The Case of Four Belgian Local Governments. Social and Environmental Accountability Journal, 38(1). Retrieved from https://doi.org/10.1080/0969160X.2018.1424644

Ding, W., Zhang, S., \& Zhao, Z. (2017). A Collaborative Calculation on Real-Time Stream in Smart Cities. In H. D. Karatza (Ed.), Simulation Modeling Practice and Theory. Elsevier. 
EuroEuropean Parliament (2014). Mapping Smart Cities in the EU. Retrieved from http://www.europarl.europa.eu/RegData/etudes/etudes/join/2014/507480/IPOL-ITRE_ET(2014)507480_EN.pdf

NYC Tech Talent Pipeline. (2015). Retrieved from http://www.tech-talentpipeline.nyc/

The Business of Cities Report for the Foresight Future of Cities Project and the Future Cities Catapult. (2014). What are Future Cities? Retrieved from https://futurecities.catapult.org.uk/resource/603/

\section{Appendix A: Distribution of Smart City Projects Amongst Five Types of Projects}

Details on five types of smart city initiatives presented in Table 1:

Table 1

Distribution of Smart City Projects Amongst Five Types of Projects

\begin{tabular}{|c|c|c|c|c|}
\hline $\begin{array}{l}\text { Smart City } \\
\text { neighbourhood units }\end{array}$ & $\begin{array}{l}\text { Testbed micro } \\
\text { infrastructures }\end{array}$ & $\begin{array}{l}\text { Intelligent traffic } \\
\text { systems }\end{array}$ & $\begin{array}{l}\text { Resource management } \\
\text { systems }\end{array}$ & Participation platforms \\
\hline \multicolumn{5}{|c|}{ Smart City characteristics typically covered: } \\
\hline $\begin{array}{l}\text { Smart Environment, Smart } \\
\text { Mobility, Smart Economy } \\
\text { and Smart Living }\end{array}$ & $\begin{array}{l}\text { Smart Environment, } \\
\text { Smart Mobility and } \\
\text { Smart Economy }\end{array}$ & $\begin{array}{l}\text { Smart Mobility and } \\
\text { Smart Environment }\end{array}$ & $\begin{array}{l}\text { Smart Environment, } \\
\text { Smart Governance, } \\
\text { Smart Economy and } \\
\text { Smart Living }\end{array}$ & $\begin{array}{l}\text { Smart Governance, Smart } \\
\text { Economy and elements of } \\
\text { other characteristics } \\
\text { depending on project scope }\end{array}$ \\
\hline \multicolumn{5}{|l|}{ Projects } \\
\hline Blue Gate Antwerp & $\begin{array}{l}\text { Amsterdam Climate } \\
\text { Street }\end{array}$ & TIDE & $\begin{array}{l}\text { Barcelona smart grids } \\
\text { and smart metering }\end{array}$ & $\begin{array}{l}\text { Amsterdam } \\
\text { Opent.nl and } \\
\text { Apps for } \\
\text { Amsterdam }\end{array}$ \\
\hline Metropolitan Bilbao & $\begin{array}{l}\text { Smart Streets of } \\
\text { Barcelona suburb Sant } \\
\text { Cugat }\end{array}$ & $\begin{array}{l}\text { Copenhagen } \\
\text { Transportation } \\
\text { Integration }\end{array}$ & $\begin{array}{l}\text { Barcelona solar } \\
\text { powered hot water } \\
\text { ordinance }\end{array}$ & Periphea \\
\hline Copenhagen Nordhavn & Cologne Klima Strasse & $\begin{array}{l}\text { Copenhagen } \\
\text { Cycling Lanes }\end{array}$ & $\begin{array}{l}\text { Bremen Environmental } \\
\text { Building Management }\end{array}$ & $\begin{array}{l}\text { Florence Open } \\
\text { Data }\end{array}$ \\
\hline Hamburg Hafen City & Glasgow Street Lighting & $\begin{array}{l}\text { Coventry } \\
\text { electricvehicle } \\
\text { infrastructure }\end{array}$ & Cologne ship-to-grid & $\begin{array}{l}\text { Helsinki Digital } \\
\text { Urban Services }\end{array}$ \\
\hline $\begin{array}{l}\text { Mass-retrofitting London } \\
\text { Neighbourood Hackbridge }\end{array}$ & $\begin{array}{l}\text { London Greenwich } \\
\text { Peninsula OS }\end{array}$ & $\begin{array}{l}\text { Dublin Road } \\
\text { Congestion } \\
\text { System }\end{array}$ & $\begin{array}{l}\text { Cologne Smart } \\
\text { metering }\end{array}$ & $\begin{array}{l}\text { Helsinki } \\
\text { Developer Portal }\end{array}$ \\
\hline Lyon Smart Community & Milan Smart Light & $\begin{array}{l}\text { Eindhoven Traffic } \\
\text { Flow System }\end{array}$ & $\begin{array}{l}\text { The Copenhagen } \\
\text { Sewerage Management } \\
\text { System (The Harbour } \\
\text { Bath) }\end{array}$ & Citadel \\
\hline Oulu Arctic City & $\begin{array}{l}\text { Tilburg Smart Street } \\
\text { Lights }\end{array}$ & $\begin{array}{l}\text { Enschede Vehicle } \\
\text { Inductive Profile }\end{array}$ & $\begin{array}{l}\text { Copenhagen } \\
\text { Middelgrunden Wind } \\
\text { Power Project }\end{array}$ & CitySDK \\
\hline Stockholm Royal Seaport & & Civitas & Gothenburg Celsius & $\begin{array}{l}\text { EU Platform for } \\
\text { Intelligent Cities } \\
\text { (EPIC) }\end{array}$ \\
\hline Tampere ECO2 & & $\begin{array}{l}\text { Tallinn Smart } \\
\text { Card System }\end{array}$ & Smart Power Hamburg & \\
\hline Vienna Aspern & & $\begin{array}{l}\text { Thessaloniki } \\
\text { Smart Mobility }\end{array}$ & Mannheim E Energy & \\
\hline & & $\begin{array}{l}\text { Zaragoza Traffic } \\
\text { Monitoring }\end{array}$ & $\begin{array}{l}\text { Miskolc Geothermal } \\
\text { Central Heating } \\
\text { Munich Smart Grid } \\
\text { System } \\
\text { Vienna Citizens' Solar } \\
\text { Power Plant } \\
\text { Aarhus Cities in Water } \\
\text { Balance }\end{array}$ & \\
\hline
\end{tabular}




\section{Zones in Smart City Neighbourhood}

The zones in smart city are described as neutral units from carbon dioxide emissions point of view and have complete smart environment, mobility, economy and life infrastructure. These have been described in the examples used in Table 1: London suburb of Hackbridge, Hafen City in Hamburg, Nordhavn in Copenhagen, Stockholm Royal Seaport, Oulu Arctic City (Finland), Lyon Smart Community, and Aspern in Vienna.

These smart city standard-neighbourhoods, built to fit 10,000 up to 40,000 inhabitants, are applied either for green fields or development/retrofit projects and are usually destined to increase the city capacity in order to meet urbanization and economic development incentive when introducing it as durability and technology outpost.

The projects have a holistic field; various neighbourhoods demonstrate complete visions of future smart city which incorporates infrastructure, smart file, and durability—at a smaller scale. Apart from objectives on energy consumption, all projects emphasizes complete energetic infrastructure: smart networks, alternative and renewable energy and waste, and water management.

All projects focus on smart life model and life quality improvement, as well as smart traffic infrastructure creation, especially when it comes to smart mobility within transportation and cycle infrastructure.

All projects have concluded public-private partnerships, which, in most cases, reflect the need of local city halls to benefit from financing and/or additional technological capacities. These are based on external partnership to bring developers' experience, funding and technology_usually a large number of private companies from financial, development, and utilities sectors, as well as local universities.

All projects aim to become neutral from fossil fuel consumption point of view and $\mathrm{CO}_{2}$ emissions point of view, but, generally, projects do not have clear objectives on reduction of energy consumption. Here, enforcement of all adaptation measures recommended for private owned households should reduce carbon emission with $51.2 \%$ in total, and energy consumption with 56\% compared to initial value in 1990.

All projects are expected to produce same type of energy reduction and improved results on efficiency, as well as a large number of positive externalities, including citizens' satisfaction, zones development, improved residential value, and increased tax base.

\section{Micro-test Infrastructures}

The second group of projects is what we called micro-test infrastructures. These projects are small city entities, used to pilot or present smart city technology, emphasizing smart environment, mobility, and economy.

The objective is to connect as many entities, sensors, and physical objects as possible in order to create and test micro-infrastructure. These operating systems are meant to manage communication between sensor and device and thus to avoid direct involvement of people. In most cases, the entity is a so-called smart or climate street, in which are connected through ICT and sensors as many physical objects as possible.

Few examples are explained in Table 1.

Applied technologies include smart energy management systems, parking assistance sensor monitoring systems, mobility sensors monitoring systems, waste sensors monitoring systems, environment sensors monitoring systems (temperature, humidity, and pollution),street light sensors monitoring systems, Wi-Fi no tax recharge stations and electric vehicles.

In all cases, there are multiple objectives, e.g., $\mathrm{CO}_{2}$ emissions reduction, money saving, economical development incentive and consolidation of local enterprises technological base (also export growth), and, most important, identifying ways to develop and extend these micro-infrastructures at city level.

\section{Smart Traffic Systems}

Traffic management with smart city projects is made through ICT systems and usually with road sensors or GPS, emphasizing 
smart mobility and environment. The objective is to monitor traffic information in real time in order to manage urban traffic in the most efficient and green way possible.

These objectives must be achieved through acceleration of solving the problems related to road networks, reducing traffic jams, and improving traffic flow.

\section{Systems of Resource Management}

A large number of smart city projects in EU targets ICT-based resources management systems, such as smart networks, smart metering, smart energy systems, and solar, wind, and hydro energy management systems.

Resource management initiatives imply in the first place the environment, management, economy, and smart life which have important characteristics. Several cities with such ongoing projects are presented in Table 1.

As in the case of other mentioned types, smart cities resources management systems are based mainly on public-private partnerships, specifically partnerships with energy or other resources suppliers, as well as specialized companies and, sometimes, local universities that bring advanced technologies for solving complex problems in the city.

\section{Participation Platforms}

ICT-based participation of the citizens covers strategies and open data platforms, publicity and co-creation platforms, as well as other forms of participation and citizens ideas. Smart city open data projects include competitions to develop applications and other digital services produced by citizens, often based on public data, used to develop better public services and to involve citizens that participate and co-produce services. Open data smart city projects usually offer better results of smart administration and economy, but the elements from other characteristics appear based on project applicability and participants' capacities/capabilities.

On the whole, the strategic objective of these projects is to develop better public services based on citizens' contribution resulted from ideas/concepts platforms used to develop a better city (Amsterdam Smart City Platform) or competitions used to profit from open public data in order to develop mash-up data or service applications. For instance, Helsinki searches for new ways to encourage the developers to exploit open data and create digital services and applications citizens may benefit from.

\section{Appendix B: Correlation Between Smart City Characteristics and Estimations}

It is important to point out that distance from (complete) prevalence is larger if there are rare characteristics, so the initiative portfolio emphasizes a little this characteristic and uses it only in few initiatives. When a characteristic is common for all initiatives, this will be at a small distance towards the ideal. As a result, for all these characteristics, it is difficult to draw conclusions regarding their contribution to success due to small variant of explanation. The characteristics situated in the middle are used more selectively, and their correlation with the score is more relevant.

According to Table 2, the most powerful positive correlations between characteristics are those between smart management and smart people, smart environment and smart mobility, smart economy, and smart life. This suggests that there is a self-sufficient acknowledgement of the spread between connex characteristics. The most powerful negative correlations (either a choice or an incompatibility amongst individual initiatives) are those between smart management and smart environment, smart mobility, and smart people, as well as between smart mobility on the one hand and smart management on the other. This doesnot mean that these characteristics are incompatible or independent, but that they are just rarely met together. As mentioned above, weighted scores based on performance and characteristic scores are more related one to another than they are related to coverage score.

Correlation between characteristics and estimations is of more direct relevance in this respect. Table 3 presents estimations for characteristics, coverage, and performance of these characteristics of the smart city (coverage width). 
Table 2

Correlation Between Characteristics and Smart City Estimations

\begin{tabular}{|c|c|c|c|c|c|c|c|c|c|}
\hline & $\begin{array}{l}\text { ECO } \\
(\%)\end{array}$ & $\begin{array}{l}\text { ENV } \\
(\%)\end{array}$ & $\begin{array}{l}\text { GOV } \\
(\%)\end{array}$ & $\begin{array}{l}\text { PEO } \\
(\%)\end{array}$ & $\begin{array}{l}\text { LIV } \\
(\%)\end{array}$ & $\begin{array}{l}\text { MOB } \\
(\%)\end{array}$ & $\begin{array}{l}\text { Characteristic } \\
(\%)\end{array}$ & $\begin{array}{l}\text { Coverage } \\
(\%)\end{array}$ & $\begin{array}{l}\text { Performance } \\
(\%)\end{array}$ \\
\hline ECO & 100 & & & & & & & & \\
\hline ENV & -10 & 100 & & & & & & & \\
\hline GOV & 38 & -81 & 100 & & & & & & \\
\hline PEO & 7 & -53 & 59 & 100 & & & & & \\
\hline LIV & 31 & -18 & 21 & -12 & 100 & & & & \\
\hline MOB & 9 & 59 & -53 & -70 & -12 & 100 & & & \\
\hline $\begin{array}{l}\text { Europe } 2020 \\
\text { characteristic score }\end{array}$ & & & & & & & 100 & & \\
\hline $\begin{array}{l}\text { Europe } 2020 \\
\text { coverage score }\end{array}$ & & & & & & & 78 & 100 & \\
\hline $\begin{array}{l}\text { Performance-weight } \\
\text { ed score }\end{array}$ & & & & & & & 95 & 79 & 100 \\
\hline
\end{tabular}

Note. Source:http://www.europarl.europa.eu/RegData/etudes/etudes/join/2014/507480/IPOL-ITRE_ET(2014)507480_EN.pdf

Table 3

Correlations Between Estimations for Characteristics, Coverage, and Performance of the Six Characteristics of Smart City

\begin{tabular}{llll}
\hline & Characteristic (\%) & Coverage (\%) & Performance (\%) \\
\hline ECO & 70 & 56 & 55 \\
ENV & -19 & -1 & 14 \\
GOV & 34 & 15 & -6 \\
LIV & 35 & 14 & 33 \\
PEO & 5 & -1 & -16 \\
MOB & 2 & 3 & 28 \\
\hline
\end{tabular}

Note. Source:http://www.europarl.europa.eu/RegData/etudes/etudes/join/2014/507480/IPOL-ITRE_ET(2014)507480_EN.pdf

On the whole, a negative score indicates a situation in which a characteristic is included without evident proof of need for emergency or it is not used when more precise performance aspects are needed (with respect to Europe 2020 Objectives). In the first case, it is possible that this characteristic is used when existent strengths represent base (for instance, for demonstrative purposes or for raising awareness). For the latter, there is a strong argument for dedicated efforts to stimulate usage of missing characteristics.

This thing demonstrates that the coverage width of the smart economic characteristics is strongly correlated with all three success factors, but the strongest with characteristic measure. This demonstrates the country economic performance is not a determining factor for including smart economy aspects. There is a certain bimodality degree present here. Countries with strong economic performance may be motivated to include this characteristic in order to consolidate their gains and to develop into a more competitive smart economy at global level. On the other side, those on weaker positions may see smart city initiatives as a partial solution to their economic problems. In both cases, characteristic correlation is strong, because comparative rarity of smart characteristics of economies because it is more likely to appear for cities closer to ideal configuration (in other words, when a city becomes closer to ideal, economic characteristics may be included last).

Because of comparative rarity of smart economic initiatives, this characteristic has the weakest relation with any of the estimation). On the other hand, comparative abundance of smart environment characteristics means that it also has a weak relation (despite the differences in correlation coefficients).

Taking into account its high prevalence, smart environment is negatively correlated with coverage and characteristic measures. More interesting seems the positive correlation with weighted performance score. This means that the highest 
environment performance is met (as expected) by those few cities which don't include smart environment in most of their initiatives.

The opposite goes for smart governance: It is positively correlated with characteristics scores and coverage scores, but also negatively correlated with weighted measure on performance. Maybe this is due to the fact that this characteristic is related to economic, educational, and social objectives. Smart cities initiatives that approach governance are, first, public initiative and, as a result, are more likely to be found in cities with relatively good performances in main measures of efficient governances. This does not mean that this characteristic is not inappropriate in these cities, but that it justifies additional measures for smart governance introduction in smart city initiatives in cities with poorer governance performance.

As life standards are closely related to economic results, the image of smart life is similar to that smart economy, although connections are less stronger due to higher smart life characteristics prevalence.

Unlike this, smart people characteristics is insufficient used in cities where most needed. This happens probably because associated actions (e.g., public information submission) are more likely to be present in advanced cities, and therefore are first candidates for application and further development in the cities, which behave well against this target, but may be premature in cities with more serious problems.

Finally, taking into account powerful associations with nice initiatives in several cities, smart mobility is weakly associated with tax free estimation, but it is more linked to weighted estimation based on performance. 